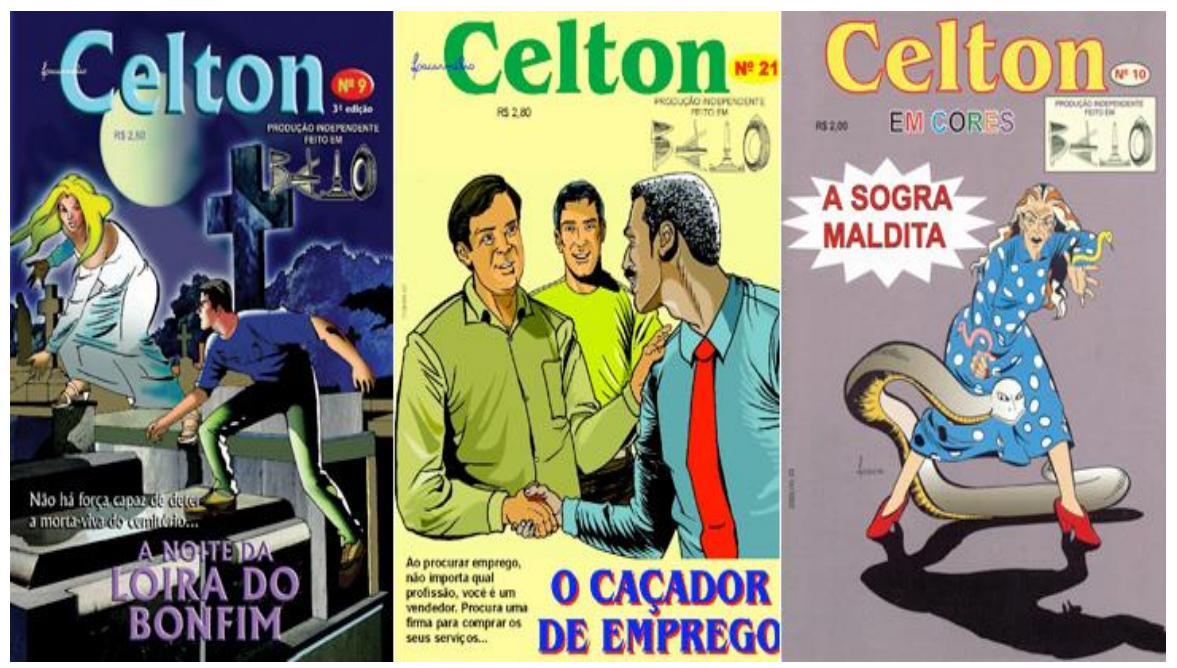

\title{
O super herói de Belo Horizonte
}

Entrevista com Lacarmélio Araújo

Por Tânia Mara Lage

Lacarmélio Araújo. É quadrinista e vende revistas em quadrinhos, que ele mesmo faz, nas ruas de Belo Horizonte. Não se importa de ser chamado pelo nome do personagem a quem deu vida: Celton.

Tânia Mara Lage. Psicóloga. Integrante do Programa A tela e o texto.

\section{Há quanto tempo você faz suas revistinhas?}

Faço minhas revistas há 28 anos. Até parei durante um período, mas logo voltei.

\section{De onde veio a inspiração?}

Na minha época os pais achavam que revista de super-herói desencaminhava as crianças. Eu gostava de ler Tarzan e revistinhas de faroeste. Na época história em quadrinho se chamava banda desenhada. A idéia nasceu desde menino, no interior, eu tinha paixão pelos livros. Lia muito HQ. Eu não tinha dinheiro para comprar ai pegava emprestado com os 
amigos. E desde pequeno era isso que eu queria ser, eu queria fazer história em quadrinho.

\section{Como surgiu o nome do personagem?}

Não queria nome de bicho - Homem -aranha, Homem-morcego então coloquei um nome fácil de pronunciar, e que fosse fácil de ser pronunciado em outras línguas também. Tem revistinha em que o Celton nem aparece, e até por isso, teve uma época que a revista passou a ser chamar Belô, mas logo depois voltou a se chamar Celton. Mesmo não tendo o personagem em todas, é a marca da revista.

\section{Você tem uma idéia de quantos clientes você tem? Você tem clientes fixos?}

Não tenho a menor idéia de quantos ou quais são os meus clientes, portanto não sei também se tenho seguidores. Escrevo e quero que leiam. Eu prefiro não esperar uma clientela fixa para não me decepcionar com as vendas.

\section{Quantas revistinhas você vende em média?}

Eu tenho que vender em média 200 exemplares por dia. Mas nem sempre vendo. Aí tenho que correr atrás no dia seguinte. No total, já editei em torno de 70 revistas.

\section{Quais são seus pontos de venda?}

Os engarrafamentos. São eles que fazem a minha venda. Até por isso meu público é variado. As vezes, quem me conhece, me liga: "Celton, tá tudo parado na rua tal!" Aí eu corro para lá. Agora estou vendendo em São Paulo também. Lá chequei a vender 1.000 exemplares num dia. Vou para lá uma vez por mês. Gosto do que faço e vivo disso, por isso, embora muitos acreditassem ser minha revista regional resolvi vender em São Paulo da mesma forma que vendo em BH. Para isso escolhi um área de grande engarrafamento, onde pretendo ficar ate ser conhecido.

\section{Só as pessoas de carro compram?}

- maior público é o das pessoas de carro, mas as pessoas que estão passando a pé também compram, ou mesmo de dentro do ônibus, me chamam e eu vou até elas. 
Como o público recebe você nas ruas?

Alguns elogiam, outros falam palavrões, mas eu não me importo com isso. O número de exemplares que eu vendo é que me diz se - exemplar agradou. E eu não incomodo, fico no meu lugar, com - cartaz. Quem quiser comprar me chama que eu vou até o carro, até a pessoa. Então quando vou é porque sei que já para vender.

\section{Você se importa de ser chamado pelo nome do personagem?}

De forma nenhuma. Ele é a minha marca.

\section{Por que o preço baixo?}

É barato para que as pessoas comprem.

\section{Você chegou a fazer contato com editoras?}

Várias vezes. Em 1980 procurei editoras no Rio de Janeiro e em São Paulo, para tentar alguma forma de trabalho. Não precisava ser como desenhista, mas eu queria apenas estar perto, ver como era para fazer. Mas não tive chance. Então eu mesmo resolvi fazer.

Você acompanhou todo o processo de revolução tecnológica. Hoje temos o computador, os programas que auxiliam na edição de imagens e textos. Você faz uso desses recursos? Eles te auxiliam de alguma forma?

Você está vendo aquelas penas de caneta ali? (aponta para a mesa onde trabalha, que está cheia de canetas e bicos de penas). Pois é, para mim o computador é mais uma daquelas penas. Eu uso o computador apenas para finalizar o trabalho. O trabalho maior é feito á mão mesmo. Acho que todas essas novas mídias despertam o interesse, o aprendizado, e então, são válidas.

\section{Como você ecolhe os temas para suas revistas?}

Não escrevo sobre política, nem faço protesto.Os assuntos vão surgindo. Trabalho muito tempo em um exemplar. Escolho assuntos que possam interessar ou fazer sentido pra o público para o qual vendo. 


\section{Qual a importância do seu trabalho?}

Proporcionar momentos de prazer e conhecimento para as pessoas. Porque, além da leitura, minhas histórias também trazem um conhecimento. E acho que isso ajuda a despertar o interesse, o gosto pela leitura.

Belo Horizonte, outubro de 2009. 